\title{
The Long Run Effect of Female Work Force Participation on Child Labour
}

\author{
Soumya Sahin ${ }^{1} \&$ Ambar Nath Ghosh ${ }^{2}$ \\ ${ }^{1}$ Assistant Professor (Economics), The West Bengal National University of Juridical Sciences, Kolkata, India \\ ${ }^{2}$ Professor, Department of Economics, Jadavpur University, Kolkata, India \\ Correspondence: Soumya Sahin, The West Bengal National University of Juridical Sciences, Dr. Ambedkar \\ Bhavan,12 LB Block, Sector-III, Salt Lake City, Kolkata, India. E-mail: soumya.sahin@gmail.com
}

Received: June 26, 2017

Accepted: July 25, 2017

Online Published: August 20, 2017

doi:10.5539/ijef.v9n9p137

URL: https://doi.org/10.5539/ijef.v9n9p137

\begin{abstract}
We develop a simple overlapping generations model to show how an increased level of female labour force participation(FLFP) could add to GDP and also make society, especially, women and children better off in the long run. It will also enumerate some of the reasons behind the gender gap in employment and suggest ways to overcome the gap.
\end{abstract}

Keywords: Child labour, female labour force participation, overlapping generations model

\section{Introduction}

The problem of child labour has been a major concern to governments and policy makers in the developing countries. Children work at the cost of their right to education as a result of which, they are forced to work as unskilled labourers even when they are adult. This creates a vicious circle of poverty. The incidence of child labour is dependent upon a number of factors. Understanding the interplay of these factors is a highly complex exercise. However, one can always look into the manner in which this incidence of child labour is defined and controlled through state policies - by simultaneously creating prohibitions against a number of actors and incentivizing child education. Studies have shown that legislations and governmental policies prohibiting child labour prove insufficient in presence of stark poverty. For example, The Child Labour (Prohibition and Regulation) Act, 1986 in India does not provide a fool-proof mechanism to monitor the occurrences of child labour; neither does it disincentivize the incidence of child labour. One has to add another perspective in this debate - the parental choice. Why does a parent prioritize "work" over "education"? What can be done to incentivize education and discourage child employment and what is the content of the "incentive" element in the legislative and governmental policies? Here, we need to realistic and understand the fact that banning child labour in a developing country like India is not a feasible option. Child labour can be considered as a necessary evil, and it is not feasible to ban or abolish it in its entirety. With a huge child population coupled with the factor that a large number of people reside below the poverty line, child labour helps sustain livelihood and provides poor and vulnerable households with an alternative source of income.

However, there is no dispute with regard to the fact that child labour per se is a bad thing and is not desirable. It can never be supported, as it has a number of negative consequences. Thanks to child labour, children only end up doing unskilled work for a substantial period of time. Child labour deprives a child of his education. As the child cannot get educated, he is deprived of the knowledge and skill that is required to be successful in later part of life.

After discussing the reasons for child labour, the authors analyse the actions of the Government to restrict and regulate child labour. We highlight the main faults in these policies, and discuss as to why there is a need to implement schemes and projects in a more efficient and result-oriented manner. We emphasize that laying more focus on education and improving education infrastructure can play a pivotal role in mitigating the problem of child labour.

We discuss a model where child education can be achieved through women empowerment. Once a woman participates in the work force, her position in the family improves and her opinions gain the much required weight-age. We conduct a literature review and attempt to show that women's empowerment and mother's 
education has a positive impact in reducing child labour. As the mother is employed and starts earning more, her role in the family and in the household becomes more prominent. She has more bargaining power and gets a greater say in all decisions that are taken in the household.

Once the mother has a greater say in household affairs, there is a likelihood that she will send her child to school, and ensure that the child is not going to work. We will substantiate this presumption in the course of the paper by trying to focus on the fact that a mother's attachment with her child is different than a father. An economically independent mother who has greater bargaining power within the household is more likely to invest a substantial part of family income in children's education. She also will have a greater propensity to ensure that the child does not enrol for work at the cost of missing school. Once more children start going to school, the number of children working start reducing. Hence, as per our analysis, women empowerment and maternal education can play a pivotal role in mitigating the menace of child labour.

\section{Reasons behind High Incidence of Child Labour in India and an Overview of Existing Regulatory Laws}

India is the second most populous country in the world with nearly $40 \%$ of its population being that of children. According to United Nation's Millennium Development Goal (MDG) programme 270 millions or $21.9 \%$ people out of 1.2 billion of Indians lived below poverty line of \$1.25 in 2011-2012. Thus it is eminent, that a major portion of the nation does not have the means to access the basic requirements of livelihood. This lack of financial stability coupled with the ever-increasing population plays a big role in promoting child labour. The father, who in most cases is the only earning member of the family, does not earn enough to meet the consumption requirements of all the members of the family. As a result, they always welcome any opportunity to earn more money. Since there is sufficient demand for unskilled labour in the economy, and child labour can partially substitute adult labour (Basu and Van, AER, 1998), there is always a possibility that they will prefer sending their children to work than to school. To them it is a necessity. The notion that their child will get educated and later in life will work as skilled labour earning higher income and prestige is often outweighed by the sheer instinct to survive at present.

Most studies have shown that the primary reason for the ongoing existence of child labour is abject poverty. The decision as to whether to send the children to the school or to work is decided upon by the parents. This is where the effect of women empowerment comes in. How empowering women will give rise to increase in child education and reduce child labour will be elaborately explained in the later segment of this paper.

There are several international organizations which play an important role in combating the issue of child labour. The two most important ones are the International Labour Organization (ILO) and the United Nations Children's Emergency Fund (UNICEF). The ILO's primary objective is to frame policies to cope with child labour throughout the world. The UNICEF on the other hand provides health care and child education for children. Both these organizations work with the belief that the main way to counter the rise in child labour is to provide every child with education.

There are three main international regulations on child labour. These are as follows:

1) The ILO convention number 38 (1973) - This convention lays down the lower limit under which a child cannot be employed. According to this convention, a child under the age of fifteen years cannot be employed.

2) The ILO convention number 182 (1999) - This convention focuses on reducing the all sorts of hazards from child labour under the age of eighteen years. It also prohibits involvement of child in bonded labour, prostitution, pornography, trafficking and other illicit activities.

3) The United Nations Convention on Rights of the Child (1989) - Majority of the countries in the world have ratified this convention. The primary objective of this convention is to make primary education compulsory and free. Out of the 54 articles of the convention, a number of articles deals with issue of child labour.

It is surprising to find that India has not yet ratified these conventions. The only major legislation which is present is The Child Labour Prohibition and Regulation Act, 1986. However the said act is not stringent enough to eradicate child labour. It does not lay a complete ban on the child labour. It allows children to work for their families and restricts them from being engaged in the work force only upto 14 years of age .

Although there are many policies in place, the problem is that, in most cases, they are not executed properly. The mere invention of policies is not just enough. The main task is their enforcement. Unless these projects are implemented properly, it is very difficult to address the situation effectively. Particularly, in rural areas, where the problem of child labour is more acute, there is severe lack of educational infrastructure and even if there are infrastructures, there is a lack of eligible teachers. So the government must increase its budgetary allocation on 
the education sector, provide better infrastructure, increase the teacher-student ratio, strengthen incentivization programmes like mid-day meal and this would help a long way in countering child labour.

There should be a reason why children prefer school over work. The primary objective of the children involved in child labour is to earn money and contribute in their family's income so that they can have a four square meal. So if they are to attend school, their valuable working hours are wasted. As long as there are no lucrative incentives to overcome that monetary loss, there is no reason why they should attend school. This has to be achieved by incentives provided by the government. Along with these incentives, the quality of education should also matter. The education that is delivered should make a child competent enough to find a job as a skilled worker in the next phase of her life.

\section{Role of Women Empowerment in Arresting Child Labour-A brief Review of Literature}

In this part of the paper, the authors conduct a literature review and attempt to show that women's empowerment and mother's education has a positive impact in reducing child labour. As the mother is employed and starts earning more, her role in the family and in the household increases. She has more bargaining power and gets a greater say in all decisions that are taken in the household. Once the mother has a greater say in household affairs, there is a likelihood that she will send her child to school, and ensure that the child is not going to work. A literate mother who has greater bargaining power is more likely to invest a major part of the household income in children's education. She also ensures that the child does not enrol for work at the cost of missing school. Once more children start going to school, the number of children who enrol themselves in work starts reducing. As a result, women's empowerment and maternal education can play a significant role in reducing child labour. It ensures that more and more children go to school, and that children do not substitute education for work. The "Standard Household Model" has been replaced by the "Collective Model". The "Collective Model" recognizes that a household's decisions depend upon the power balance between the husband and the wife.

To improve the female labour force in the rural areas, better infrastructure and transportation system is necessary along with making clean water easily available (Koolwal \& Van de Walle, 2013). This will facilitate women's access to the markets and reduce their time spent on domestic chores. Access to electricity and water sources have led an increase in FLFP by 9 percent in South Africa (World Bank, 2012).

Childcare is an important issue. In Japan, 70 percent of women quit their job for at least ten years when their first child is born (Kawabata, 2014). Childcare facilities like implementation of day care centres, tax benefits can help to reduce the burden. Successful examples are publicly provided or subsidized day care such as Estancias Infantiles in Mexico and Hogares Comunitaros in Colombia (World Bank, 2012). In France, the state provides child infrastructure and allows parents to employ a nanny and offset that cost against their tax burden (Pricewaterhouse Coopers, 2007).

There should be sufficient provisions for efficiently designed family benefits and publicly financed parental leave schemes. A rapid return to the workplace after giving childbirth will mitigate the impact of a shrinking labour force due to the same and help shift the underlying gender norms. Hence, policies that provide and encourage greater parity between paternity and maternity should be implemented (International Monetary Fund, 2013).

Mandatory paternity leave schemes have been introduced in Iceland and Norway. Sweden implemented a scheme where one part of paternity leave is earmarked for the father and forfeited in case he chooses to not utilize it. Also better and affordable childcare facilities should be provided. The elasticity of female labour supply is directly related to the price of the childcare and varies between -0.13 to -0.2 . Decreasing the cost of childcare facilities by $50 \%$, the female labour supply increases in the order of 6.5 percent to 10 percent. This decreasing cost, in turn opens up the mother's time, who will now devote her time efficiently to both childrearing but also to her workplace(Kalb, 2009; Gong, Breunig, \& King, 2010).

Education plays an important part in determining the women human capital. There is a positive relationship between education and human capital. An increase in the expenditure on education of women will thereby lead to a rise in the FLFP. Expenditure on women's education and improvements in rural infrastructure can boost FLFP in emerging and developing countries ( Laframboise \& Trumbic, 2003). In Turkey, only 17 percent of the illiterate women form a part of the FLFP, whereas 70 percent of literate women form the FLFP (Ercan, Hosgor, \& Yimlaz, 2010). Bhalla and Kaur predict that the FLFPR in urban India can increase by almost 13 percent points when more educated women join in the labour force (Bhalla \& Kaur, 2011).

Female labour force participation is directly affected by taxation of labour income and Government spending on social welfare benefits. "The tax systems impose strong disincentives for FLFP through high tax wedges on 
secondary earners" (Stotsky, 1996). Often married women are at a disadvantage when family income tax is levied on the concerned household. Therefore, the taxing system should impose individual income taxes instead. This measure will be effective in France, Portugal and US (International Monetary Fund, 2013).

The taxation system followed in Belgium, Germany, Finland, Sweden and Netherlands employs phasing out of credit with individual income rather than family income. This results in an increase of FLFP as the marginal tax rate applied to the secondary earners will generally remain lower (International Monetary Fund, 2013).

Proper and unbiased pension schemes should also be implemented. The female labour force should not be inhibited by lower pensions owing to their absence from the workplace during their maternity leave. Chile, France, Germany and Sweden have introduced a pension reform scheme where they provide special credits to women with children (International Monetary Fund, 2013).

The low-wage earners should be given tax credits in order to stimulate the labour force participation, including that of women.

There should be ample policies to promote economic opportunities for women. Economic success of a woman is directly correlated to the economic opportunities she faces. There should be communication strategies that target at reducing stereotypes and biases. The Bolsa familia direct cash transfer programme in Brazil suggest that the program has led to an increase in FLFP (Soares, Ribas, \& Osorio, 2007). It also increased women's financial independence as enumerated in SIGI (2012). The Pronaf-Mulher credit line, which targeted women's development in the rural Brazilian areas shows that there has been a direct increase in the women's rural development financing programs. An increase to almost 26 percent from some 15 percent between 2001 and 2006 has been registered (International Monetary Fund, 2013).

To improve the economic circumstances, close collaboration with international financial institutions is essential. "In their joint Global Monitoring Report on confronting the challenges of Gender Equality and Fragile States, the IMF and the World Bank (2007) argue that gender equality and empowerment of women are central to the development agenda because gender equality makes good economic sense and helps advance other development objectives, including education, nutrition, and reduced child mortality" (International Monetary Fund, 2013, p.17)

In Netherlands, the breakdown in barriers between full-time and part-time job contracts as well as the implementation of well compensated parental leave led the female labour force participation rate to increase from 35 percent in 1980 to more than 80 percent in 2008. Norway introduced a 40 percent quota for women on the boards of publicly traded companies. This led to an increase in women on boards from 9 percent in 2003 to 40 percent in 2008. Sweden with its generous and flexible parental leave policy with a high coverage rate for child care, job guarantees and eligibility for reduced working hours has a gender gap of only 6 percent. Similar improvements are observed globally (International Monetary Fund, 2013).

The authors shall refer to two Research Papers to further elucidate their argument.

\section{[A]. Das and Mukherjee (2007)}

In a Research Paper titled "Role of women in Schooling and Child Labour Decision: The Case of Urban Boys in India" Saswati Das and Diganta Mukherjee (Note 1) empirically analyse the relationship between mother's education and schooling. They analyse whether mother's education (as a proxy for giving her more say in household affairs) leads to a reduction in the child dropout rate, and thereby has a positive impact in reducing child labour. They also explore the role of women's education in exploring and improving the child's human capital scenario in light of a changing social pattern and economic opportunities.

In their paper, the authors refer to other studies that highlight the positive role that mother's education plays in human capital outcomes. They refer to the study conducted by Janssens (2004) that scrutinized the Mahila Samakhya Programme in rural Bihar, which promoted female education. As per their findings, the programme played a pivotal role in increasing female education in Bihar. An increase in female education thus led to increased parental awareness on the value of preschool and primary education.

Through this study, it can be inferred that the level of education of the mother plays a significant role in reducing school dropout rate and child labour incidence. The mother's education bears an intrinsic link with the social and human capital outcomes in the family. Empowerment of women through education and employment is certainly necessary to improve school education, and for ensuring that children do not substitute school for work.

While this study plays a crucial role in highlighting the relationship between mother's education and child labour incidence, it has certain shortcomings. The authors base their findings solely on the basis of data available for 
urban boys, and girls are not taken into consideration. There may be significant differences between rural and urban tendencies, as well as between male and female characteristics. As a result, this study does not present a holistic view of all ground realities.

\section{[B]. Shunsuke Sakamoto (2006)}

In an Article titled "Parental Attitudes towards Children and Child Labour: Evidence from Rural India" Shunsuke Sakamoto (Note 2) empirically investigates the determinants of child labour in rural India using household survey data. This is one of the few studies that pays specific and particular attention to parents' attitudes towards their children in the household as a crucial determinant of child labour. The purpose of this particular study is to provide empirical evidence that household's decision on child labour is associated with the parents' attitudes towards their children. The author investigates as to how parents' attitudes towards their children affect the incidence of child labour. Also, they investigate as to how the incidence of child labour is affected by the bargaining power between the mother and the father in the household.

The authors estimate a probit model and arrive at a finding that children are more likely to work only when their parents show less concern for them. The authors also show that children are more likely to work if their father has more bargaining power in the household, in place of the mother.

Greater the parents' concern for their children, greater is the level of consumption of child goods relative to adult goods. Based on the collective household model, the authors attempt to investigate how the balance of bargaining power between the father and the mother affects the household's decision on child labour. In order to identify the differences between father's and mother's attitudes towards their children, the authors rely on empirical results from earlier studies that explore patterns of resource allocation using the collective household model. For example, Quisumbing and Maluccio (2003) have investigated how the balance of bargaining power between the husband and the wife affects resource allocation in the household, and have used household survey data from 4 developing countries. As per their findings, in Bangladesh and South Africa, greater bargaining power of a wife substantially raises the share of education expenditure in total household expenditure. In other words, wives are more likely than husbands to prefer investing in education. Based on this result, the authors in this paper hypothesise that wives are more likely to send their children to school, instead of work. Mothers will also not allow the child the substitute school for work. Educated mothers place greater value on investment in education. They are more likely to send their children to school, and will not allow them to miss school and go for work. Giving a greater bargaining power to the mother in household decisions is likely to reduce the incidence of child labour. This is because a mother is more likely to understand the value and importance of education. She is more likely to send her child to school, and not to work. Another important conclusion that the author arrives at is that child labour is a reflection of the father's thought process, perspective and preference. They state that child labour occurs because the father prefers to send the child to work, and not to school.

\section{The Theoretical Model}

We present a simple Overlapping Generations Model where there are large numbers of identical firms and households. Following Lucas (1988), the model seeks to capture the link between individual's decision to invest in education and per capita growth. Investment in education or acquisition of skill is referred to as investment in human capital formation. Also, the paper aims at exploring the intrinsic relationship between mother's employment and its impact on the incidence of child labour. This is a long run model and ignores the problems that arise out of inadequate demand, i.e. we assume that employment and size of labour force are closely related. There is no unemployment when the size of the labour force increases. There are two groups of economic agents; Households and Firms. We assume that the total number of Households and firms in the industry is given and that there is no population growth. All the markets are perfectly competitive.

\subsection{Households}

In every period, each household consists of parents and two children. Henceforth, we will refer to the two children as a child unit. The underlying assumption is that the parents don't differentiate between children, so this is a simple normalization. Every individual lives for two periods - in the first period, she is a child and in the second period, she is a parent. Parents are the decision-makers in Households. For simplicity, the model abstracts from physical capital or investment in physical capital. Production is carried out with human capital only. Human capital is defined as labour in efficiency units. In every period, the parents in a Household have a given amount of human capital, say $\mathrm{h}_{t}$. The father supplies this human capital fully to the market. The mother has to attend to domestic chores and also because of lack of infrastructure, lack of security, social prejudices etc. can only supply a fraction, $\beta$ of her human capital to the market. 
where $\frac{\partial \beta}{\partial N} \succ o, \frac{\partial \beta}{\partial L} \succ 0, \frac{\partial \beta}{\partial E} \succ 0$.

Here, $\mathrm{N}$ represents the level of infrastructure, $\mathrm{L}$ represents the state of law and order and $\mathrm{E}$ represents the level of educational attainment of the community. Both parents consume the whole of their income, i.e. there is no savings in this model. However, while the mother contributes the whole of her income to family consumption, the father contributes only $Y$ fraction of his income to family consumption and uses the rest for his personal consumption. The child is assumed to inherit her parent's human capital. In every period, the child in each household can work and thereby contribute to the income of the household or the child can study. In fact, in this model, the child can devote a part of her income, $\phi_{t}$, to acquisition of skill or education, and the remaining (1 $\phi_{t}$ ) to work.

The parents decide how their child should allocate her given endowment of time or human capital between work and human capital formation. This is the only choice problem of the parents. For simplicity, let us assume that that the mother is the decision-making authority.

There is a one-period lag between investment in human capital and acquisition of it. The time or human capital a child invests in human capital formation in a given period enables her to acquire additional human capital in the next period. Thus the only cost of acquiring skill is the loss in household's income due to the time devoted by the child to skill acquisition instead of working in the market. All other costs of skill acquisition are ignored here for simplicity. The production function for human capital is given by:

$$
h_{t+1}=h_{t}+\mu \cdot \phi_{t} \cdot h_{t}, \quad \mu>0
$$

Equation (2) states that if $\Phi_{t} \cdot h_{t}$ amount of human capital is devoted to human capital formation by the children, their human capital will increase in the next period by $\mu$. $\Phi_{t} \cdot h_{t}$.

Parents derive utility from their household consumption in the current period and also from the amount of human capital their children will acquire in the next period. Utility function of the parents in period $t$ is given by

$$
U_{t}=\alpha \log C_{t}+(1-\alpha) \log h_{t+1}
$$

where $U_{t}$ is the utility derived by the parents in period $\mathrm{t}, C_{t}$ is the household's consumption in period $\mathrm{t}, \mathrm{h}_{\mathrm{t}+1}$ represents the human capital acquired by the children in period $t+1$ due to their investment in human capital formation in period t. $\alpha$ is the preference parameter.

Now in period $t$, parents supply $\left(\beta_{t} \cdot h_{t}+h_{t}\right)$ amount of human capital to the market and the children supply $\{2(1$ $\left.\left.-\Phi_{t}\right) . h_{t}\right\}$ amount of human capital. Thus in period $t$, the total amount of human capital supplied by the household is

$$
H_{t}=\left\{\beta_{t} \cdot h_{t}+h_{t}+2\left(1-\phi_{t}\right) \cdot h_{t}\right\}
$$

\subsection{Firms}

In this model, the firms produce a single consumption good using only human capital. Their production function is given by:

$$
Y=A H
$$

Where $\mathrm{H}$ denotes the amount of human capital used in production. There are thus two markets in this model: a market for produced consumption goods and a market for human capital.

From (5), it follows that the marginal productivity of human capital is A. Assuming perfect competition in all markets, we get

$$
\mathrm{w}_{t}=\mathrm{A} \text {, where } \mathrm{w}_{t} \text { is the real wage rate of human capital in period } \mathrm{t} \text {. }
$$

Therefore, from equation (4), we get that by selling $H_{t}$ amount of human capital, the household earns $w_{t} \cdot\left\{\beta_{\mathrm{t}} \cdot \mathrm{h}_{\mathrm{t}}+\right.$ $\left.\mathrm{h}_{\mathrm{t}}+2\left(1-\Phi_{t}\right) \cdot \mathrm{h}_{\mathrm{t}}\right\}$ amount of income in terms of the good produced. Equation (4) denotes the supply of human capital by a household. In the long run, there is no supernormal profit and the whole output accrues to the workers as their wage income. Also, it has to be noted that the demand for labour is perfectly elastic at the at the real wage rate $\mathrm{w}_{\mathrm{t}}$. Substituting (4) in (5), we get

$$
\mathrm{Y}_{t}=\mathrm{w}_{t} \cdot\left\{\beta_{t} \cdot \mathrm{h}_{t}+\mathrm{h}_{t}+2\left(1-\phi_{t}\right) \cdot \mathrm{h}_{t}\right\}
$$




$$
\text { and } \mathrm{C}_{t}=\mathrm{w}_{t} \cdot\left\{\beta_{t} \cdot \mathrm{h}_{t}+\mathrm{Yh}_{t}+2\left(1-\phi_{t}\right) \cdot \mathrm{h}_{t}\right\}
$$

The only choice problem of the household is that it has to decide how much of the human capital the child will devote to skill acquisition and how much to work. Therefore, the choice variable of the household is $\varphi_{t}$. We assume that the mother, who is the decision-making unit in this case derives satisfaction from both family consumption, denoted by $C_{t}$ and her child's future skill, denoted by $h_{t+l}$. Her objective function can be written as

$$
\text { Maximize } \mathrm{U}_{t}=\alpha \log \left[\mathrm{w}_{t} \cdot\left\{\beta_{t} \cdot \mathrm{h}_{t}+\Upsilon \cdot \mathrm{h}_{t}+2\left(1-\phi_{t}\right) \cdot \mathrm{h}_{t}\right\}\right]+(1-\alpha) \log \left[\mathrm{h}_{t}+\mu \cdot \phi_{t} \cdot \mathrm{h}_{t}\right] \text {. }
$$

Setting $\frac{\partial U_{t}}{\partial \phi_{t}}=0$, we get

$$
\varphi^{*}=(1-\alpha) \cdot\left(\frac{\gamma}{2}+\frac{\beta}{2}+1\right)-\frac{\alpha}{\mu}
$$

The solution of equation (8) is shown in figure 1 where $\varphi_{t}$ is measured on the horizontal axis and $\frac{(1-\alpha) \cdot \mu}{1+\mu \phi_{t}}$ and $\frac{2 \alpha}{\gamma+\beta+2\left(1-\phi_{t}\right)}$ are measured on the vertical axis. The former gives the marginal benefit of raising $\varphi_{t}$ and the latter gives the marginal cost of raising $\varphi_{t}$. A unit rise in $\varphi_{t}$ implies that the children supply $\mathrm{h}_{t}$ amount less of labour. Therefore, children's wage income and therefore household's income and consumption falls by $\mathrm{w}_{t} \cdot \mathrm{h}_{t}$. This leads to a fall in household's utility. Now, a unit fall in consumption leads to a $\frac{2 \alpha}{\mathrm{w}_{\mathrm{t}} \cdot \mathrm{h}_{\mathrm{t}} \cdot\left\{\gamma+\beta+2\left(1-\phi_{t}\right)\right\}}$. Thus, when consumption falls by $\mathrm{w}_{t} \cdot \mathrm{h}_{t}$, utility falls by $\frac{2 \alpha}{\gamma+\beta+2\left(1-\phi_{t}\right)}$. Therefore, this is the marginal cost of increasing $\varphi_{t}$. A unit rise in $\varphi_{t}$ also has a positive impact on household's utility by increasing the amount of human capital for the child in period t that she will acquire in the next period. This amount is given by $\mu . \mathrm{h}_{t}$.

[From equation (2), $\mathrm{h}_{t+1}=\mathrm{h}_{t}+\mu \cdot \phi_{t} \cdot \mathrm{h}_{t}$. Therefore, $\left.\frac{\partial h_{t+1}}{\partial \phi_{t}}=\mu \cdot \mathrm{h}_{t}.\right]$.

If children's future human capital increases by one unit, following equation (4), household's utility increases by

$$
\frac{\partial U_{t}}{\partial h_{t+1}}=\frac{(1-\alpha)}{h_{t}\left(1+\mu \phi_{t}\right)}
$$

Hence, when $\mathrm{h}_{t+1}$ increases by an amount $\mu . \mathrm{h}_{t}$, household's utility increases by $\frac{(1-\alpha) \cdot \mu}{1+\mu \phi_{t}}$. Therefore, this is the marginal benefit of increasing $\varphi_{\mathrm{t}}$.

At the optimum, marginal benefit of raising $\varphi_{t}=$ marginal cost of raising $\varphi_{t}$.

The point of intersection of the MB and MC curves, E in figure 1 gives the optimal value of $\varphi$, viz. $\varphi^{*}$.

Consider a value of $\varphi_{t}$, say $\phi_{0} \prec \phi^{*}$. At $\phi_{0}$, MB of increasing $\phi_{t}$ is greater than the MC of increasing $\phi_{t}$ by $\mathrm{AB}$. This implies that if $\varphi$ is raised from $\varphi_{0}$ by one unit, the gain in household's utility due to increase in future human capital of the children is given by $\mathrm{A} \varphi_{0}$, while the loss in household's utility due to reduction in household consumption is $\mathrm{B} \varphi$.

Now, $B \varphi_{0}<A \varphi_{0}$, i.e. the net gain in household's utility is $\left(A \varphi_{0}-B \varphi_{0}\right)=A B$. Thus it is optimal for households to increase $\varphi$ from $\varphi_{0}$. Similarly, for $\phi_{1} \succ \phi^{*}$, it is optimal for households to reduce $\varphi_{t}$. Hence at equilibrium, MB = $\mathrm{MC} \Rightarrow \varphi_{\mathrm{t}}=\varphi^{*}$. 


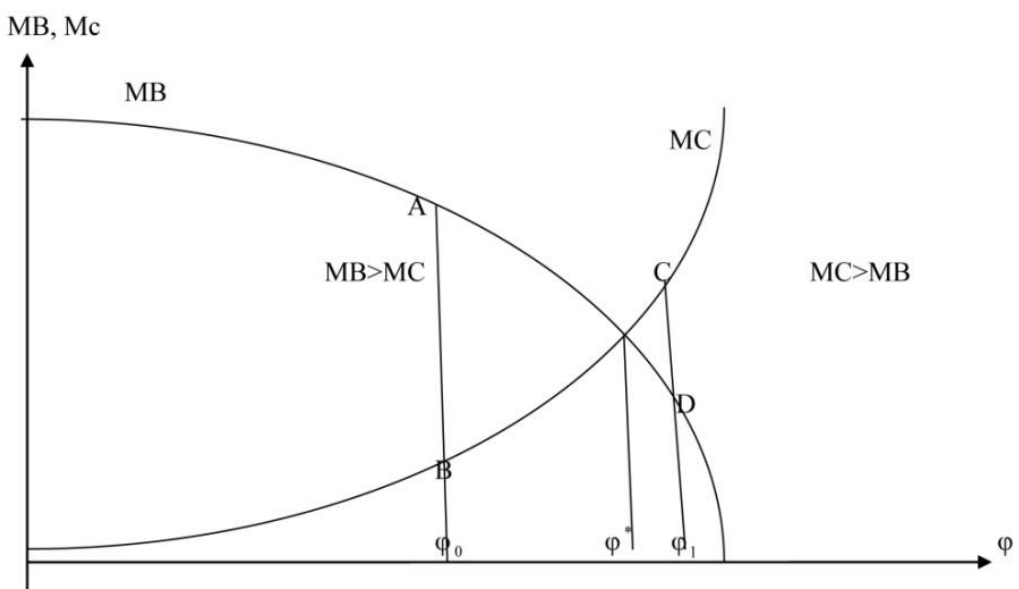

Figure 1. Determination of equilibrium value of $\varphi$

Now, from equation 8 , we get that the optimal value of $\varphi_{t}$ is independent of the real wage rate $\mathrm{w}_{t}$. It is a function of the preference parameter $\alpha ; \mu$, the parameter of human capital formation; $\beta$, the fraction of human capital a woman can supply to the market and $\Upsilon$, the fraction of income that a man contributes to household consumption.

The supply of labour in period $\mathrm{t}$ is therefore

$$
\begin{gathered}
H_{t}=\left\{1+\beta_{t}+2\left(1-\varphi^{*}\right)\right\} \cdot h_{t} \\
\text { or } H_{t}=\left[1+\beta_{t}+2\left\{1-\frac{\mu(1-\alpha)\left(\frac{\gamma}{2}+\frac{\beta}{2}+1\right)-\alpha}{\mu}\right\}\right] \cdot h_{t}
\end{gathered}
$$

Therefore, wage income in period $\mathrm{t}=$ equilibrium output in period $\mathrm{t}$ is given by the equation :

$$
\begin{gathered}
Y_{t}=A H_{t} \\
\text { or } \mathrm{Y}_{t}=\text { A. }\left[1+\beta_{t}+2\left\{1-\frac{\mu(1-\alpha)\left(\frac{\gamma}{2}+\frac{\beta}{2}+1\right)-\alpha}{\mu}\right\}\right] \cdot \mathrm{h}_{t}
\end{gathered}
$$

It has to be noted that under perfect competition, the value of aggregate output accrues fully as wage income to the households.

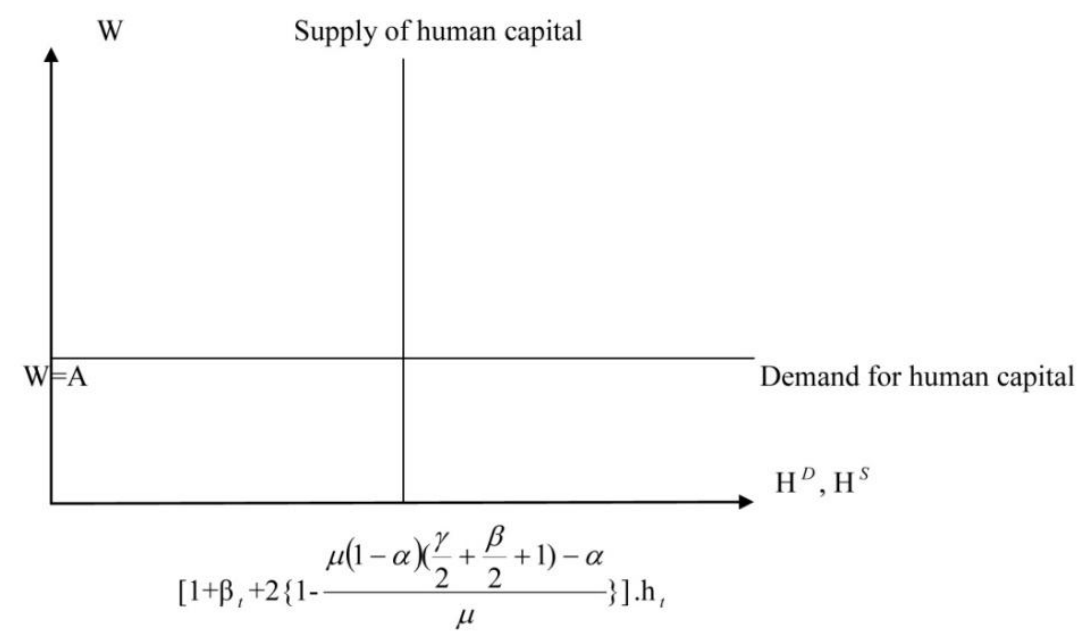

Figure 2. Determination of wage rate

In Figure 2, we show the demand for and supply of human capital on the horizontal axis and the real wage rate 
on the vertical axis.

The demand for human capital function is horizontal at $\mathrm{w}=\mathrm{A}$, where $\mathrm{A}$ is the marginal and average productivity of human capital. The supply of human capital is given by equation 9 .

Since $\varphi^{*}$ is the same in every period, the equilibrium value of aggregate output in period $t+1$, as follows from equation (10) is

$$
Y_{t+1}=A \cdot\left[1+\beta_{t}+2\left\{1-\frac{\mu(1-\alpha)\left(\frac{\gamma}{2}+\frac{\beta}{2}+1\right)-\alpha}{\mu}\right\}\right] \cdot h_{t+1}
$$

Therefore, the rate of growth of aggregate output, $\frac{Y_{t+1}-Y_{t}}{Y_{t}}$ is given by

$$
\frac{Y_{t+1}-Y_{t}}{Y_{t}}=\frac{h_{t+1}-h_{t}}{h_{t}}
$$

The human capital formation function (2), yields that

$$
\frac{Y_{t+1}-Y_{t}}{Y_{t}}=\frac{h_{t+1}-h_{t}}{h_{t}}=\mu \varphi^{*}=\mu(1-\alpha) \cdot\left(\frac{\gamma}{2}+\frac{\beta}{2}+1\right)-\alpha
$$

Therefore in this model, aggregate output and human capital from the child grow at the same constant rate over time. Since population growth is zero here, per capita output also grows at the same constant rate as the aggregate output. The economy is therefore in a steady state. From equation (13), we find that the per capita growth rate is an increasing function of $\varphi^{*}$. We can therefore easily show how the parameters of the model affect per capita growth rate using Figure 1. If parents derive more utility from current consumption and less from future human capital of child, i.e. if $\alpha$ becomes larger, then marginal cost schedule shifts upwards and marginal benefit schedule shifts downwards. Hence, $\varphi^{*}$ will fall reducing per capita growth rate. Again, if parents give more importance to child's human capital formation, the marginal cost schedule shifts downwards and marginal benefit schedule shifts upwards leading to an increase in $\varphi^{*}$. Thus the model attributes higher per capita growth rate of a country to a higher value of $\mu$ and a lower value of $\alpha$.

The Effect of an Increase in $\beta$

$\beta$, the fraction of a woman's human capital increases with an increase in the state of infrastructure, $\mathrm{N}$; law and order condition, L; and educational level of the society, E. An increase in N, L or E raises $\beta$, which in turn reduces the marginal cost for each level of $\varphi$. Therefore, the marginal cost schedule in Figure 1 will shift downward while the marginal benefit schedule will remain unaffected. Therefore, the equilibrium value of $\varphi^{*}$ will increase raising the per capita growth rate. A higher value of $\varphi^{*}$ indicates that the child will devote more time to education and less to labour.

With a rise in $\mathrm{N}, \mathrm{L}$ or $\mathrm{E}, \beta$ will increase and this will lead to an increase in $\varphi$. Hence, we can now write:

$$
\begin{gathered}
\Phi=\varphi(N, L, E) \\
\frac{\partial \phi}{\partial N} \succ 0, \frac{\partial \phi}{\partial L} \succ 0, \frac{\partial \phi}{\partial E} \succ 0 .
\end{gathered}
$$

Thus, an increase in employment opportunities of women will lead to a fall in child labour and increase the level of human capital in the economy. This gives rise to a dynamic gain. If $\mathrm{N}$ rises in period $\mathrm{t}, \beta_{t}$ will increase which will lead to a rise in $\varphi_{t}^{*}$. This raises the level of education of the society in the next period, $E_{t+1}$. Hence, in the next period, the level of $\beta$ and $\varphi$ will increase, i.e. $\beta_{t+1}>\beta_{\mathrm{t}}$ and $\varphi_{t+1}^{*}>\varphi_{t}^{*}$. This process will continue over time until $\varphi$ assumes its maximum attainable value.

\section{Conclusion}

We have discussed with the help of existing literature how more females in labour market would boost the economy and improve the well-being of people. We have developed a theoretical model to further explain our statements. We find that women's participation can be increased by an improvement in factors like infrastructure, education and security. We also find that an increase in women's participation leads to a fall in child labour. 
When women get jobs they earn a lot more than just wages. Jobs afford them a degree of independence, freedom, and dignity. Jobs give women more liberty, improve their standing both in the family and the community, expand their social circles, and improve their skills.

With better employment prospects, women can significantly contribute to the economic development, especially in the developing countries. A better control over income and earning opportunities enables them to do so. Hence, an efficient way of utilising the available talent pool would include the employment of women on an equal basis.

According to an article in "The Economist" women have contributed more to the economy that either new technology, or China and India (The Economist, 2006). For aging countries like Japan an increase in FLFP is a necessity to maintain growth. In fact, the Prime Minister of Japan Shinzo Abe has instructed Japanese businesses to increase the percentage of women in management positions from the current 10 percent to 30 percent by 2020 (The New York Times, 2014). Not only does an increase in FLFP add to growth, it also augments gender equity which is a global priority. However only more job opportunities is not enough. The ILO concept of decent work is "Opportunities for women and men to obtain decent and productive work in conditions of freedom, equity, security and dignity" (World Bank, 2012). Therefore the idea is to include more women and in such a way that their dignity and safety is not compromised. The OLG model developed in this paper also suggests that if the government improves law and order situation to provide more safety to women; if i provides infrastructure to reduce domestic work load of women, the benefits will be far reaching. The incidence of child labour will go on falling and the level of education of the community will go on rising over time.

\section{References}

Anonymous. (n. d.). Give Girls a Chance. Tackling child labour a key to future. ILO, 57.

Anonymous. (n. d.). World Report on Child Labour: Economic Vulnerability, Social Protection and the Fight Against Child Labour. ILO.

Bhat, B. A., \& Rather, T. A. (2009). Child labour in the handicrafts home industry in Kashmir: A Sociological Study. International NGO Journal, 391. Retrieved from http://www.academicjournals.org/ingoj

Lana, O. (2014). Child Labour, the effect on child, cause and remedies to the evolving menace. University of Lund, Sweden, (2014).

Lucas, Jr., R. E. (1988). On the Mechanics of Economic Development. Journal of Monetary Economics, 22, 3-42. North Holland.

Myron, W. (1991). The Child and The State In India: Child Labour and Education Policy in Comparative Perspective. Population and Development Review, 531. Retrieved from http://www.jstor.org/stable/1971955

Raynor, J., \& Wesson, K. (2006). The girls' stipend program in Bangladesh. Journal of Education for International Development.

Saswati, D., \& Diganta, M. (2007). Role of Women in Schooling and Child Labour Decision: The Case of Urban Boys in India. Social Indicators Research, 82(3).

Shunsuke, S. (n. d.). Parental Attitudes towards Children and Child labour: Evidence from Rural India. Discussion Paper Series, No. 136, Institute of Economic Research, Hitotsubashi University.

Yadav, S. K., \& Sengupta, G. (2009). Environmental and Occupational Health Problems of Child Labour: Some Issues and Challenges for Future. J. Hum. Ecol., 28(2), 143.

\section{Notes}

Note 1. Saswati Das \&Diganta Mukherjee, Role of Women in Schooling and Child Labour Decision: The Case of Urban Boys in India, Social Indicators Research, Vol. 82, No. 3 (July 2007).

Note 2. Shunsuke Sakamoto, Parental Attitudes towards Children and Child labour: Evidence from Rural India, Discussion Paper Series, No. 136, Institute of Economic Research, Hitotsubashi University.

\section{Copyrights}

Copyright for this article is retained by the author(s), with first publication rights granted to the journal.

This is an open-access article distributed under the terms and conditions of the Creative Commons Attribution license (http://creativecommons.org/licenses/by/4.0/). 